\title{
ANALISIS PRODUKTIVITAS GALIAN/ TIMBUNAN MENGGUNAKAN ALAT BERAT PADA PEMBANGUNAN BENDUNGAN MARGATIGA LAMPUNG TIMUR
}

\author{
Septyanto Kurniawan ${ }^{1}$, Ma'ruf Nuzola ${ }^{2}$ \\ Prodi Teknik Sipil Universitas Muhammadiyah Metro ${ }^{1,2}$ \\ E-mail : s_yan_k@ymail.com ${ }^{1}$, nuzola20@gmail.com²
}

\begin{abstract}
ABSTRAK
Dalam pelaksanaan proyek pembangunan pekerjaan tanah bisa dilakukan langsung dengan tenaga manusia (manual) atau menggunakan bantuan tenaga mesin (alat-alat berat). Pemilihan metode konstruksi atau kerja yang akan dipilih, tentunya tidak lepas dari pertimbangan-pertimbangan teknis dan ekonomis. Di bidang teknik sipil, alat-alat berat digunakan untuk membantu manusia dalam melakukan pekerjaan pembangunan suatu struktur bangunan. Saat ini, alat berat merupakan faktor penting di dalam proyek, terutama proyek-proyek kontruksi dengan skala besar. Penggunaan alat berat dalam pembangunan Bendungan Margatiga Kabupaten Lampung Timur bertujuan untuk memperlancar jalanya pembangunan. Kombinasi alat berat merupakan salah satu cara untuk menentukan alat berat yang akan dipakai, jumlah alat berat yang akan dipakai dan menghitung waktu dan biaya yang dibutuhkan oleh setiap kombinasi alat berat yang akan dipakai. Pekerjaan galian dan timbunan pada pembangunan bendungan Margatiga Kabupaten Lampung Timur membutuhkan beberapa kombinasi alat berat untuk menyelesaikannya. Maka dari itu dibutuhkan beberapa kombinasi alat berat untuk mengetahui produktivitas alat.

Total pekerjaan alat berat adalah $14.118 \mathrm{~m}^{3}$ yang terdiri dari pekerjaan galian sebesar 13.020 dan pekerjaan timbunan sebesar 1.098. Untuk produktivitas Excavator SANY SY305 116,64 m³ jam (menggali dan memuat kedalam Dumptruck), Excavator SANY SY365 233,29 $\mathrm{m}^{3} /$ jam (menggali dan memuat kedalam Dumptruck), ‘bratorry Roller SAKAI SV515D 159,75 $\mathrm{m}^{3} /$ jam (menggilas dan memadatkan), Dumptruck kapasitas 24

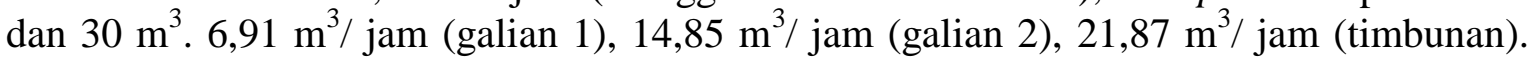
Analisa biaya sewa alat menggunakan satuan harga sewa yang ada dilokasi penlitian. Untuk hasil perhitungan analisis lapangan didapat penggunaan biaya alat berat untuk pekerjaan galian dan timbunan membutuhkan waktu 100 jam, dengan biaya sewa alat berat sebesar 629.200.000. Dari hasil perhitungan alternatif 1 didapatkan alat berat membutuhkan waktu 95 jam dengan mengerjakan pekerjaan dengan volume yang ada dilapangan, dengan total biaya sewa alat berat sebesar 597.075.000, sedangkan dari hasil perhitungan alternatif 2 didapatkan waktu 204 jam dengan total biaya sewa sebesar 1.257.660.000. Untuk hasil tanah galian yang tidak terpakai akan diangkut ke lokasi pembuangan sedangkan tanah yang terpakai digunakan untuk timbunan dinding muka apron hulu.
\end{abstract}

Kata Kunci : Produktivitas, Volume, Biaya Sewa Alat Berat.

\section{PENDAHULUAN}

Dikondisi pekerjaan yang tidak menentu menjadi hambatan untuk produktivitas alat berat seperti faktor hujan, material galian, kondisi jalanatau medan pekerjaan, kapasitas alat berat yang dipakai dan keahlian operator. 
Waktu siklus alat berat menjadi faktor yang sangat penting untuk diperhatikan, terutama dalam pekerjaan pemindahan material hasil galian. Kondisi jalan dari lokasi galian menuju lokasi timbunan atau lokasi pembuangan harus dalam kondisi baik untuk mendukung waktu siklus alat berat, semakin cepat waktu siklus alat berat maka produktivitas alat berat pun akan menjadi lebih besar. Lama pekerjaan alat berat akan berpengaruh terhadap biaya sewa alat berat, pergantian suku cadang, pergantian pelumas, oli dan ban alat berat. Maka penting untuk memperhitungkan produktivatas dari kombinasi alat berat yang akan dipakai dalam pekerjaan khusus nya pemindahan tanah.

Pembangunan Bendungan Margatiga Kabupaten Lampung Timur mengoprasikan alat berat diantaranya Excavatorsebanyak 2 unit, Buldozer sebanayak 2 unit, Dumptruck $24 \mathrm{~m}^{3}$ dan $30 \mathrm{~m}^{3}$, sebanyak 12 unit, dan Vibratory Roller sebnayak 1 unit. Bendungan Margatiga Kabupaten Lampung Timur direncanakan bertipe urugan batu dengan inti lempung, dengan tinggi $20 \mathrm{~m}$, dengan luas genangan $\pm 2.257 \mathrm{Ha}$ dan daya tampung efektif $68.887 .000 \mathrm{~m}^{3}$, total luas lahan yang terkena dampak dari pembangunan bendungan, seluas 449.991,5396 $\mathrm{m}^{2}$. Maka dengan volume pekerjaan yang sangat besar Penggunaan alat berat sangat dibutuhkan demi kelancaran pembangunan tersebut. Pemindahan tanah menjadi faktor penting dalam pembangunan Bendungan, peran alat berat dalam pekerjaan tanah untuk galian, timbunan, pemadatan menjadi pekerjan awal dari pembanguan bendungan Margatiga Kabupaten Lampung Timur.

Untuk mengetahu produktivitas dari kombinasi alat berat yang ada dilokasi pekerjaan disini peneliti ingin mengetahui faktor-faktor apa aja yang mempengaruhi untuk produktivitas alat berat yang setiap alat mempunyai fungsi yang berbeda-beda namun saling keterkaitan satu sama lain. Hambatan yang terjadi saat pengerjaan galian dan timbunan akan mempengaruhi untuk lama pekerjaan yang berimbas kepada biaya sewa alat yang membesar, karena untuk biaya sewa alat berat dihitung dalam pemakaian satuan jam. Penting mencari kombinasi alat yang terbaik untuk memaksimalkan kinerja dari masing-masing alat berat. Kapasitas alat berat yang besar dapat mempercepat menyelesaikan volume pekerjaan yang ada dilokasi pekerjaan. Terutama kapasitas dari alat berat Dumptruck sebagai pengangkut atau pemindah tanah hasil galian, dan Excavator sebagai alat penggali sekaligus pemuat ke dalam Dumptruck.

\section{TINJAUAN PUSTAKA}

\section{Dasar-Dasar Pemindahan Tanah Mekanis}

Material yang ada di alam pada umumnya tidak Homogen, melainkan merupakan material campuran. Material juga bervariasi dari jenis material yang berpori sampai yang padat. Dengan keadaan yang bervariasi seperti ini maka pada saat melakukan pemilihan alat berat yang akan dipakai di dalam proyek kontruksi otomatis jenis material di lapangan dan material yang akan dipakai merupakan hal yang perlu diperhatikan (Ahmad Kholil, 2012:7).

\section{Sifat-Sifat dan Jenis Tanah}

Material di suatu tempat atau dapat dikatakan di tempat asalnya disebut dengan material asli atau Bank Material. Jika suatu bagian dari material akan dipindahkan maka volume material yang dipindahkan akan berubah menjadi lebih besar daripada volume material ditempat asalnya. Material yang dipindahkan tersebut disebut dengan material lepas atau Loose Material. Demikian pula jika material yang telah dipindahkan kemudian dipadatkan maka volume material akan menyusut. Material 
yang telah dipadatkan disebut sebagai material padat atau Compacted Material. Hampir seluruh material yang telah dipadatkan mempunyai volume yang lebih kecil dari pada volume tanah asli atau material di tempat asalnya.

Hal ini disebabkan pemadatan dapat menghilangkan atau memperkecil ruang atau pori di antara butiran material, akan tetapi batuan pecah mempunyai volume tanah asli (Bank Volume) hampir sama dengan volume tanah yang dipadatkan (Compacted Volume). Pasir dan lempung padat tertentu bahkan mempunyai Compacted Volumelebih besar daripada Bank Volume (Ahmad Kholil, 2012:8).

\section{Waktu Sikus}

Siklus kerja dalam pemindahan material merupakan suatu kegiatan yang dilakukan berulang. Pekerjaan utama di dalam kegiatan tersebut adalah menggali, memuat, memindahkan, membongkar muatan, dan kembali ke pekerjaan awal. Semua kegiatan tersebut dapat dilakukan oleh suatu alat atau beberapa alat. Waktu yang diperlukan di dalam siklus kegiatan diatas disebut waktu siklus atau Cycle Time (CT). Waktu siklus terdiri dari beberapa unsur yaitu sebagai berikut :

1. Waktu muat atau Loading Time (LT)

Waktu muat merupakan waktu yang dibutukan oleh suatu alat untuk memuat material ke dalam alat angkut sesuai dengan kapasitas alat angkut tersebut. Nilai LT dapat ditentukan walapun bergantung dari jenis tanah, ukuran unit pengangkut (Blade, Bowl, Bucket, dan seterusnya), metode dalam pemuatan dan efisiensi alat

2. Waktu angkut atau Loading Time (HT)

Waktu yang diperlukan oleh suatu alat untuk bergerak dari tempat pemuatan ke tempat pembongkaran. Waktu angkut bergantung dari jarak angkut, kondisi jalan, tenaga alat dan lain-lain. Pada saat alat kembali ke temapat pemuatan maka waktu yang diperlukan untuk kembali disebut waktu kembali atau Retum Time (RT). Waktu kembali lebih singkat daripada waktu berangakat karena kendaraan dalam keadaan kosong

3. Waktu pembongkaran atau Dumping Time (DT)

Merupakan unsur penting dari waktu siklus ini bergantung pada jenis tanah, jenis alat, dan metode yang dipakai. Waktu pembongkaran merupakan bagian terkecil dari waktu siklus.

4. Waktu tunggu atau Spotting Time (ST) Merupakan waktu pada saat alat kembali ke tempat pemuatan adakalanya alat saat mengantri dan menunggu ini di sebut waktu tunggu.

\section{Produktivitas dan Durasi Pekerjaan}

Dalam menentukan durasi suatu pekerjaan maka hal-hal yang perlu diketahui adalah volemu pekerjaan dan produktivitas alat tersebut.

$$
\text { Produktivitas }=\frac{\text { Kapasitas }}{C T}
$$

Umunya waktu siklus alat ditetapkan dalam menit sedangkan produktivitas alat dihitung dalam produksi/ jam. Jika factor efisiensi alat dimasukkan, maka rumus di atas menjadi :

$$
\text { Produktivitas }=\text { Kapasitas } x \frac{60}{C T} x \text { Efisiensi }
$$

Pada umunya dalam suatu pekerjaan terdapat lebih dari satu jenis alat yang dipakai. Jumlah alat perlu diperhitungkan untuk mempersingkat durasi pekerjaan, salah satu cara menghitung jumlah alat berat adalah sebagai berikut :

$$
\text { Jumlah }_{\text {alat } 1}=\frac{\text { Produktivitas }_{\text {terbesar }}}{\text { Produktivitas }_{\text {alat } 1}}
$$

Setelah jumlah masing-masing alat diketahui maka selanjutnya perlu dihitung durasi pekerjaan alat-alat tersebut, salah satu caranya dengan menentukan berapa produktivitas total alat setelah dikalikan jumlahnya, dengan menggunakan produktivitas total terkecil maka lama pekerjaan dapat dicari dengan menggunakan rumus:

$$
\text { Durasi }=\frac{\text { Volume }_{\text {pekerjaan }}}{\text { Produktivitas }_{\text {terkecil }}}
$$




\section{Alat Gali (Excavator)}

Excavator adalah alat berat yang terdiri dari lengan (arm), Boom (bahu) serta Buckhet (alat keruk) Dab digerakan oleh tenaga Hidrolis yang dimotori dengan mesin dan berada diatas roda rantai (Trackshoe). xcavator digunakan untuk menggali material yang letaknya diatas permukaan di mana alat tersebut berada. Alat ini mempunyai kemampuan untuk menggali material yang keras dan lunak. Pengoperasian Backhoe umunya penggalian saluran, terowongan atau basement. Backhoeterdiri dari enam bagian utama, yaitu struktur atas yang dapat berputar, Boom, lengan (arm), Bucket, Slewing Ring, dan struktur bawah. (susy fatena rostiyanti, 2008:93)

Produksi Excavator dapat dihitung dengan menggunakan persamaan (Rochmanhadi 1985:28).

$$
\begin{aligned}
& Q=\frac{q \times 3600 \times E}{c m} \\
& \text { Dimana } Q \quad=\text { produksi per jam }\left(\mathrm{m}^{3} / \mathrm{jam}\right) \\
& \mathrm{q}=\text { produksi per siklus }\left(\mathrm{m}^{3}\right) \\
& \mathrm{Cm} \quad=\text { waktu siklus (detik) } \\
& \mathrm{E} \quad=\text { efesiensi kerja }
\end{aligned}
$$

Produksi per siklus:

$$
q=q_{1} \times K
$$

Dimana: $\quad q_{1}=$ kapasitas munjung menurut SEA (didalam spesifikasi) $\mathrm{K}=$ faktor Bucketyang besarnya tergantung tipe dan keadaan tanah

\section{Dozer (Bulldozer)}

Dozeratau Bulldozermerupakan traktor yang dipasangkan pisau atau Blade di bagian depanya. Pisau berfungsi untuk mendorong, atau memotong material yang ada di depanya, jenis pekerjaan yang biasanya menggunakan Dozer atau Buldozer. Produksi Buldozer perjam dapat dihitung dengan menggunakan persamaan sebagi berikut. (Rochmanhadi 1985:17)

$$
\begin{aligned}
& Q=\frac{q \times 60 \times E}{C m} \mathrm{~m}^{3} / \mathrm{jam}, \mathrm{cu} . \mathrm{yd} / \mathrm{jam} \\
\text { Dimana: } \mathrm{q} & =\text { Produksi per siklus }\left(\mathrm{m}^{3}, \mathrm{cu}, \mathrm{yd}\right) \\
\mathrm{Cm} & =\text { Waktu siklus (dalam menit) } \\
\mathrm{E} & =\text { Efesiensi kerja }
\end{aligned}
$$

Produksi per siklus

$$
q=L \times H^{2} \times a
$$

dimana : $\mathrm{L} \quad=$ Lebar sudu (blade), $(\mathrm{m}, \mathrm{yd})$

$$
\mathrm{H} \quad=\text { Tinggi sudu (blade), }(\mathrm{m}, \mathrm{yd})
$$

\section{Vibratory Roller}

Vibratory Roller (penggilas getar) mempunyai efesiensi pemadatan yang sangat baik. Alat ini memungkinkan digunakan secara luas dalam tiap jenis pekerjaan pemadatan. Efek yang diakibatkan oleh Vibratory Rolleradalah gaya dinamis terhadap tanah. Butir-butir tanah cenderung mengisi bagian-bagian kosong yang terdapat di antara butirbutirnya. Sehingga akibat getaran ini tanah menjadi padat dengan susunan yang lebih kompak (Tenrisukki, 2003). Menghitung produktivitas dalam volume tanah yang dipadatkan menggunakan rumus berikut :

$$
Q=\frac{W x V \times H \times 1000 x E}{N}
$$

$$
\begin{aligned}
& \text { Dimana: } \\
& \mathrm{Q} \quad=\text { produksi per jam }\left(\mathrm{m}^{3} / \mathrm{jam}\right) \text { (volime tanah yang } \\
& \text { dipadatkan) } \\
& \text { = kecepatan operasi }(\mathrm{km} / \mathrm{jam}) \\
& =\text { lebar pemadatan efektif tiap pass }(\mathrm{m}) \\
& =\text { tebal pemadatan untuk satu lapis }(\mathrm{m}) \\
& =\text { jumlah pemadatan } \\
& =\text { efesiensi kerja dari pas-pas yang dilalui. }
\end{aligned}
$$

Menghitung produktivitas dalam satuan luas menngunakan rumus sebagai berikut (Rochmanhadi, 1985: 58) :

$$
Q_{A}=\frac{W x V \times 1000 x E}{N}
$$

Dimana:

$Q_{A}=$ luas per jam tanah yang dipadatkan $\mathrm{m}^{2} / \mathrm{jam}$

\section{Dumptruck}

Dumptruck adalah alat pengangkut yang dapat berkecepatan tinggi ketika melaju di jalan raya. Dumptruck dapat juga mempunyai kapasitas yang besar dengan biaya per-unit volume rendah. Dumptruck juga mempunyai fleksibilitas tinggi dalam kapasitas angkut, karena jumlah truk dapat disesuaikan dengan kebutuhan proyek. Waktu siklus 
Damptruck $=1+2+3+4+5$. (Rochmanhadi 1985:32)

$$
C m_{s}=\text { n. } C m_{s}+\frac{D}{V 1}+t 1+\frac{D}{V 2}+t 2
$$

Produksi per siklus Dumptruck dapat dihitung dengan rumus sebagai berikut :

$$
\begin{aligned}
& \text { Dimana } \quad C=n \times q_{1 x} \times K \\
& \mathrm{n}=\text { jumlah siklus yang diperlukan Excavator mengisi Dumptruck } \\
& \mathrm{q}_{1}=\text { kapasitas Bucket } \\
& \mathrm{K}=\text { faktor Bucket Excavator }
\end{aligned}
$$

Produksi per jam total dari Dumptruck yang mengerjakan pekerjaan yang sama secara simultan dapat dihitung dengan rumus (Rochmanhadi, 1985:42) :

$$
\begin{array}{ll}
\text { Dimana } & P=\frac{C \times 60 \times E}{C m t} \\
\mathrm{P} & =\text { produksi per jam }\left(\mathrm{m}^{3} / \mathrm{jam}\right) \\
\mathrm{C} & =\text { produksi per siklus }\left(\mathrm{m}^{3} / \mathrm{jam}\right) \\
\mathrm{E}_{\mathrm{t}} & =\text { efesiensi kerja Dumprtuck } \\
\mathrm{C}_{\mathrm{mt}} & =\text { waktu siklus Dumptruck (menit) } \\
\mathrm{M} & =\text { jumlah Dumprtuck yang bekerja }
\end{array}
$$

\section{Kapasitas Produksi}

Kapasitas produksi alat berat pada umumnya dinyatakan dalam $\mathrm{m}^{3}$ jam. Produksi didasarkan pada pelaksanaan volume yang dikerjakan tiap siklus waktu dan jumlah siklus satu jam (Rochmanhadi 1985).

$$
\begin{aligned}
& Q=q \times N \times E=q \times \frac{60}{c m} \times E \\
& \text { Dimana: } \quad \mathrm{Q} \quad=\text { Produksi per jam }\left(\mathrm{m}^{3} / \mathrm{jam}\right) \\
& \mathrm{q}=\text { Produksi per siklus }\left(\mathrm{m}^{3}\right) \\
& \mathrm{N} \quad=\text { Jumlah siklus per jam, } \mathrm{n}=60 \mathrm{~cm} \\
& \mathrm{E} \quad=\text { Efesiensi kerja } \\
& \mathrm{Cm}=\text { Waktu siklus dalam menit }
\end{aligned}
$$

\section{METODE PENELITIAN}

Dalam penelitian ini peneliti ingin mengetahui produktivitas alat berat dalam pekerjaan galian dan timbunan. Metode pengambilan data secara langsung pada lokasi yang telah ditentukan. Data akan diambil dari lokasi penelitian yaitu pembangunan bendungan Margatiga Kabupaten Lampung Timur,
Desa Negeri Jemanten Dan Desa Trisinar. Yang akan ditinjau yaitu waktu siklus, produksi per siklus, produksi per jam, volume pekerjaan, biaya penggunaan atau sewa alat berat dan biaya perawatan alat berat.

\section{Teknik Sampling}

Teknik sampling adalah teknik yang dilakukan untuk menentukan sampel. Jadi sebuah penelitian yang baik haruslah memperhatikan dan menggunkan sebuah teknik dalam menetapkan sampel yang akan diambil sebagai objek penelitian. Dalam hal ini peneliti mengambil objek penelitian alat berat, dengan penelitain dilakukan secara langsung dilokasi penelitian, adapaun alat berat yang diteliti adalah 2 unit Excavator dengan kapasitas Bucket 2,1 dan 0,8 $\mathrm{m}^{3}, 2$ unit Bulldozer kapasitas Blade 4,4 $\mathrm{m}^{3}$, Vibratory Roller kapasitas mesin gilas 10,5 ton dan 12 unit Dumptruck dengan kapasitas 24 dan $30 \mathrm{~m}^{3}$

\section{Teknik Analisis Data}

Teknik analisis data merupakan pengolahan terhadap data-data yang telah dikumpulkan yaitu data primer dan sekunder yang didapat dari lokasi penelitian. Analisis yang digunakan pada penelitian ini, yaitu analisis mengenai produktivitas alat berat untuk pekerjaan galian dan timbunan dengan menggunakan perhitungan secara manual. Dari pengolahan data ini peneliti berharap dapat mengetahui produktivitas dari masing-masing alat berat. Adapun data yang akan di analisis dilokasi penelitian adalah sebagi berikut :

a. Spesifikasi dari masing-masing alat berat

b. Jam operasional kerja

c. Jenis material yang ada dilokasi penelitian

d. Waktu per siklus dari masingmasing alat berat

e. Jarak angkut material (jarak dari tempat pemuatan material menuju tempat pembongkaran) 
f. Produksi dari masing-masing alat berat per siklus dan dalam satu jam siklus, yang dihitung dalam satuan $\mathrm{m} 3$ /jam)

g. Menghitung biaya operasional dan biaya penggunaan atau sewa alat berat menggunakan harga satuan yang ada dilokasi penelitian.

h. Melakukan perhitungan analisis lapangan dan 2 analisis alternatif untuk mencari waktu dan harga sewa alat berat yang terbaik atau paling ekonomis.

- Analisis lapangan adalah perhitungan produktivitas alat berat dengan jumlah, kombinasi, kapasitas alat berat yang ada dilokasi penelitian, adapun alat berat dalam perhitungan lapangan adalah 2 unit Excavator dengan kapasitas 2,1 dan $0,8 \mathrm{~m}^{3}, 2$ Bulldozer kapasitas Blade 4,4 m, 1 Vibratory Roller kapasitas 10,5 ton, 12 Dumptruck kapasitas 24 dan 30 $\mathrm{m}^{3}$.

- Analisis alternatif 1 adalah perhitungan produktivitas alat berat dengan spesifikasi alat berat yang digunakan sama dengan yang ada di lapangan, namun untuk jumlah unit dan kapasitas alat berat di kombinasikan yaitu, 2 unit Excavator kapasitas 2,1 m3 dan 10 unit Dumptruck kapasitas $24 \mathrm{~m} 3$. Untuk Vibratory Roller dan Bulldozer kapasitas dan jumlah unit sama dengan analisis lapangan.

- Analisis alternatif 2 adalah perhitungan produktivitas alat berat dengan spesifikasi alat berat yang digunakan sama dengan yang ada di lapangan, namun untuk jumlah unit dan kapasitas alat berat di kombinasikan yaitu, 2 unit Excavator kapasitas 0,8 m3 dan 10 unit Dumptruck kapasitas $30 \mathrm{~m} 3$. Untuk Vibratory Roller dan Bulldozer kapasitas dan jumlah unit sama dengan analisis lapangan.

\section{HASIL PENELITIAN}

Penelitian ini adalah Pembangunan bendungan Margatiga Kabupaten Lampung Timur. Data umumyang diperoleh antara lain :

Tabel 1. Daftar Unit dan Harga Sewa Alat Berat Pada Pembangunan Bendungan Margatiga Lampung Timur

\begin{tabular}{|c|c|c|c|c|c|}
\hline Nama Alat & Type Alat & Kode Unit & Kapasitas & Harga Sewa jam & Tahun Pembuatan \\
\hline \multirow[t]{12}{*}{ Damptuck } & 1.DT NISSAN CWB45 ALDN & 106 & $24 \mathrm{~m}^{3}$ & 217.500 & 2010 \\
\hline & 2. DT NISSAN CWB45 ALDN & 112 & $24 \mathrm{~m}^{3}$ & 217.500 & 2010 \\
\hline & 3. DT NISSAN CWB45 ALDN & 124 & $24 \mathrm{~m}^{3}$ & 217.500 & 2010 \\
\hline & 4. DT NISSAN CWB45 ALDN & 103 & $24 \mathrm{~m}^{3}$ & 217.500 & 2011 \\
\hline & 5. DT NISSAN CWB45 ALDN & 115 & $24 m^{3}$ & 217.500 & 2011 \\
\hline & 6. DT NISSAN CWBA5 ALDN & 117 & $24 \mathrm{~m}^{3}$ & 217.500 & 2011 \\
\hline & 6. DT MITSUBISHI FUSO 220 PS & 01 & $30 \mathrm{~m}^{3}$ & 217.500 & 2015 \\
\hline & 7. DT MTSUBISH FUSO 220 PS & 02 & $30 \mathrm{~m}^{3}$ & 217.500 & 2015 \\
\hline & 8. DT HINO FM 260 JD & 108 & $30 \mathrm{~m}^{3}$ & 217.500 & 2010 \\
\hline & 9. DT HNOFM 260 JD & 125 & $30 \mathrm{~m}^{3}$ & 217.500 & 2012 \\
\hline & 10. DT HINOF FM 260 JD & 105 & $30 \mathrm{~m}^{3}$ & 217.500 & 2013 \\
\hline & 11. DTHNOFM 260.JD & 102 & $30 \mathrm{~m}^{3}$ & 217.500 & 2017 \\
\hline \multirow[t]{2}{*}{ Excavator } & 1. EXCAVATOR SAIY SY305H & 03 & $0,8 \mathrm{~m}^{3}$ & 235.000 & 2020 \\
\hline & 2. EXCAVATOR SAIY SY365H & 02 & $2,1 \mathrm{~m}^{3}$ & 235.000 & 2019 \\
\hline \multirow[t]{2}{*}{ Buldozer } & 1. D85ESS-2 & 08 & $4,4 m^{3}$ & 335.000 & 2013 \\
\hline & 2. D85ESS-2 & 102 & $4,4 \mathrm{~m}^{3}$ & 335.000 & 2011 \\
\hline Vbratory Roller & 1. SAKAI SV515D & 01 & 10,5 ton & 2850000 & 2012 \\
\hline
\end{tabular}

Tabel 2. Jadwal Pekerjaan Alat Berat Pada Pembangunan Bendungan Margatiga Lampung Timur

\begin{tabular}{|c|c|c|c|c|c|c|c|c|c|}
\hline \multirow[b]{2}{*}{ Tanggal } & \multirow{2}{*}{$\begin{array}{c}\text { Jam } \\
\text { Operasional } \\
\text { Kerja }\end{array}$} & \multicolumn{4}{|c|}{ Jumalah Alat Berat Yang Bekerja } & \multirow[b]{2}{*}{ Cuaca } & \multirow[b]{2}{*}{ Keterangan } & \multirow[b]{2}{*}{$\begin{array}{c}\text { Jenis } \\
\text { Material }\end{array}$} & \multirow[b]{2}{*}{ Pekerjaan } \\
\hline & & Excavator & Damporock & Bulloozer & $\begin{array}{l}\text { Vibratory } \\
\text { Roller }\end{array}$ & & & & \\
\hline 080712020 & 11 & 2 & 12 & 2 & 1 & Cerah & Lembur & T. Berimpur & Galian \\
\hline 090712020 & 11 & 2 & 12 & 2 & 1 & Ceranh & Lembur & T. Beriumpur & Galian \\
\hline 100712020 & 11 & 2 & 11 & 2 & 1 & Cerah & Lembur & T. Berimpur & Galian \\
\hline 110712020 & 11 & 2 & 10 & 2 & 1 & Cerah & Lembur & T. Berlumpur & GalianRTimbunan \\
\hline 120712020 & 11 & 2 & 9 & 2 & 1 & Cerah & Lembur & T. Berlimpur & Galian\& Timbunan \\
\hline 130712020 & 11 & 2 & 10 & 2 & 1 & Cerah & Lembur & T. Berimpur & Galian \\
\hline 140772020 & 4 & 2 & 8 & 2 & 1 & Hujan & Tidak & T. Berlumpur & Galian \\
\hline 150712020 & 11 & 2 & 10 & 2 & 1 & Cerah & Lembur & T. Berlumpur & Galian \\
\hline 1610712020 & 8 & 2 & 10 & 2 & 1 & Cerah & Trodk & T. Beriumpur & Galian \\
\hline 170712020 & 11 & 2 & 10 & 2 & 1 & Cerah & Lembur & T. Berimpur & Galian \\
\hline Total & 100 & 20 & 102 & 20 & 10 & & & & \\
\hline Ratarata & 10 & 2 & 10,2 & 2 & 1 & & & & \\
\hline
\end{tabular}

Tabel 3. Produksi Pekerjaan Galian dan Timbunan Pembangunan Bendungan Margatiga Lampung Timur

\begin{tabular}{|c|c|c|c|c|c|c|c|}
\hline \multirow[b]{2}{*}{ Tanggal } & \multicolumn{6}{|c|}{ Produksi dan Jenis Pekerjaan Alat Berat $\left(\mathrm{m}^{3}\right)$} & \multirow[b]{2}{*}{ Jam Kerja } \\
\hline & $\begin{array}{l}\text { Rek Jalan } \\
\text { Inpeksi Ke } \\
\text { Arah Jetty }\end{array}$ & $\begin{array}{l}\text { Galian Lantai } \\
\text { Hilir (Tanaha) }\end{array}$ & $\begin{array}{l}\text { Galian Lantai } \\
\text { Hilir (Pasir) }\end{array}$ & $\begin{array}{l}\text { Galian Hilir } \\
\text { Bendung }\end{array}$ & $\begin{array}{c}\text { Trmbunan } \\
\text { Lantai Muka } \\
\text { Apron Hut }\end{array}$ & $\begin{array}{c}\text { Total } \\
\text { Pekejaanilari }\end{array}$ & \\
\hline $08807 / 2020$ & - & 304 & - & 612 & - & 916 & 11 \\
\hline 09107/2020 & . & 696 & . & 666 & . & 1.362 & 11 \\
\hline 1010772020 & . & 864 & . & 852 & & 1.716 & 11 \\
\hline 111072020 & . & . & . & 1.692 & 258 & 1.950 & 11 \\
\hline 12072020 & . & 234 & . & 1.152 & 840 & 2.226 & 11 \\
\hline 13/1072020 & & . & 756 & 792 & . & 1.548 & 11 \\
\hline 14:07/2020 & . & . & 342 & 234 & . & 576 & 4 \\
\hline 15107/2020 & - & - & 428 & 906 & - & 1.334 & 11 \\
\hline 1610712020 & . & . & 404 & 774 & . & 1178 & 8 \\
\hline $17707 / 2020$ & . & . & 304 & 1.008 & . & 1.312 & 11 \\
\hline Total Pekerjaan & & 2098 & 2234 & 8.688 & 1.098 & 14.118 & 100 \\
\hline Total Produksi & & & & $14.118 \mathrm{~m}^{3}$ & & & \\
\hline
\end{tabular}


Bedasarkan table 3 diatas jumlah produksi dalam jangka waktu 10 hari adalah sebanyak $14.118 \mathrm{~m}^{3}$, terdiri dari pekerjaan Galian sebanyak $13.020 \mathrm{~m}^{3}$ dan pekerjaan Timbunan sebanyak $1.098 \mathrm{~m}^{3}$.

Tabel 4. Rekapitulisai Waktu Siklus Dan Produktivitas Alat Berat

\begin{tabular}{|c|c|c|c|c|}
\hline Jenis Alat Berat & $\begin{array}{c}\text { Jumlah } \\
\text { Unit }\end{array}$ & $\begin{array}{l}\text { Waktu } \\
\text { Siklus } \\
\text { (Jam) }\end{array}$ & $\begin{array}{c}\text { Produksi } \\
\text { Per Siklus } \\
\left(\mathrm{m}^{3}\right)\end{array}$ & $\begin{array}{l}\text { Produksi } \\
\mathrm{m}^{3} / \mathrm{jam}\end{array}$ \\
\hline $\begin{array}{l}\text { Excavator SANY } \\
\text { SY365H }\end{array}$ & 1 & 0,00583333 & 1,68 & 233,29 \\
\hline $\begin{array}{l}\text { Excavator SANY } \\
\text { SY305H }\end{array}$ & 1 & 0,00555556 & 0,64 & 116,64 \\
\hline Bulldozer & 2 & 0,01116667 & 5,5 & 369,40 \\
\hline Vibratory roller & 1 & - & - & 159,75 \\
\hline Dumptruck galian 1 & 5,2 & 0,225 & 1,92 & 6,91 \\
\hline Dumptruck galian 2 & 5,2 & 0,27483333 & 5,04 & 14,85 \\
\hline Dumptruck timbunan & 5,2 & 0,1866667 & 5,04 & 21,87 \\
\hline
\end{tabular}
produktivitas dan biaya penggunaan atau sewa alat berat serta biaya pekerja pada Pembangunan

Bendungan Margatiga Lampung Timur, untuk Pekerjaan galian dan timbunan.Dengan volume pekerjaan yang ada dilapangan serta kombinasi alat berat yang digunakan didalam pekerjaan pemindahan tanah secara mekanis. Penelitian berlangsung selama 10 hari dengan total jam kerja alat berat selama 100 jam dengan rata-rata jam kerja per hari $10 \mathrm{jam}$. Jumlah alat berat yang digunakan pada lokasi pembangunan Bendungan Margatiga Lampung Timur adalah 2 Excavator dengan kapasitas Buckhet 2,1 dan 0,8 m3,Bulldozer kapasitas Blade 4,4 m3, Vibratory Roller kapsitas mesin gilas 10.5 ton dan Dumptruck kapasitas bak 24 dan $30 \mathrm{~m} 3$, untuk Dumptruck memiliki jenis atau merek yang berbeda, serta jumlah pengoperasianya tidak sama setiap harinya.

Tabel 5. Rekapitulisai Perawatan Alat Berat dan Kebutuhan Bahan Bakar.

\begin{tabular}{|c|c|c|c|c|c|c|c|}
\hline \multirow{2}{*}{ Jenis Alat Berat } & \multirow{2}{*}{$\begin{array}{l}\text { Jam } \\
\text { Kerja }\end{array}$} & \multirow{2}{*}{$\begin{array}{c}\text { Jumlah } \\
\text { Unit }\end{array}$} & \multirow{2}{*}{$\begin{array}{l}\text { Kebutuhan } \\
\text { Bahan Bakar }\end{array}$} & \multicolumn{2}{|c|}{ Kebutuhan $\mathrm{Oli}$} & \multicolumn{2}{|c|}{ Biaya Perawatan } \\
\hline & & & & olihydraulic & oliengine & oli hydraulic & di engine \\
\hline Excavafor SANY SY365H & 10 & 1 & $35 \mathrm{U}$ jam & $200 \mathrm{~L} 2000 \mathrm{jam}$ & $25 \mathrm{U} 250 \mathrm{jam}$ & 4.832600 & 1.009 .600 \\
\hline Excavator SANY SY3O5H & 10 & 1 & 29U Jam & $200 \mathrm{~L} 2000 \mathrm{jam}$ & $25 \cup 250 \mathrm{jam}$ & 4.832 .600 & 1.009 .600 \\
\hline Bulloozer & 10 & 2 & 35L Jam & $200 \mathrm{~L} 2000 \mathrm{jam}$ & $40 \cup 250 \mathrm{jam}$ & 9.665 .200 & 3.230 .720 \\
\hline Vibratory Roller & 10 & 1 & $7 \mathrm{~J}$ jam & $200 \mathrm{~L} 2000 \mathrm{jam}$ & $17 \cup 250 \mathrm{jam}$ & 4.832 .600 & 686.528 \\
\hline Dumptrock & 10 & 102 & 10U jam & 30 U5 Bulan & $35 \mathrm{U} 3$ bulan & 7.393 .878 & 14.417 .088 \\
\hline Total Biaya Perawalan A & & & & & & 31.556 .878 & 20.353 .536 \\
\hline
\end{tabular}

Tabel 6. Biaya Penggunaan Alat Berat Pada Pekerjaan Galian dan Timbunan Bendungan Margatiga Lampung Timur

\begin{tabular}{|c|c|c|c|c|}
\hline \multirow{2}{*}{ Jenis Alat Berat } & \multirow{2}{*}{ Jumlah Unit } & \multirow{2}{*}{ Total Jam Kerja } & \multicolumn{2}{|c|}{ Biaya Penggunaan Biaya Sewa Alat Berat } \\
\hline & & & Per Jam & Total Jam Keija \\
\hline Excavator SANY SY365H & 1 & 100 jam & 605.000 & 60.500 .000 \\
\hline Excavator SANY SY305H & 1 & 100 jam & 545.000 & 54.500 .000 \\
\hline Bullober & 2 & 100jam & 1.350 .000 & 135.000 .000 \\
\hline Vibratory roller & 1 & $100 \mathrm{jam}$ & 375.000 & 37.500 .000 \\
\hline Dumptruck & 10,2 & $100 \mathrm{jam}$ & 3.417 .000 & 341.700 .000 \\
\hline Total Biaya Seva Alat Berat & & & & 629.200 .000 \\
\hline
\end{tabular}

Dalam pekerjaan galian ada dua lokasi titik galian di Pembangunan Bendungan Margatiga Lampung Timur, digunakan 2 alat berat Excavator yang bekerja di titik galain yang berbeda, dan di kombinasikan dengan Dumptruck sebagai alat pengangkut tanah hasil galian ke lokasi pembuangan. Tanah hasil galian galian dititik 1 semuanya diangkut ke lokasi pembuangan, sedangkan dititk galian 2 ada yang digunakan sebagai timbunan di lantai muka apron hulu.

Tabel 7. Biaya Upah Operator Alat Berat

\begin{tabular}{ccccc}
\hline Jenis Alat Berat & Jumlah Alat & $\begin{array}{c}\text { Upah } \\
\text { Operator } \\
\text { Per Jam }\end{array}$ & $\begin{array}{c}\text { Jumlah } \\
\text { Jam } \\
\text { Kerja }\end{array}$ & $\begin{array}{c}\text { Jumlah } \\
\text { Upah } \\
\text { Operator }\end{array}$ \\
\hline Excavator & 2 unit & 20.000 & 100 & 4.000 .000 \\
Bulldozer & 2 unit & 20.000 & 100 & 4.000 .000 \\
Vibratory Roller & 1 unit & 20.000 & 100 & 2.000 .000 \\
$\begin{array}{c}\text { Dumptruck } \\
\text { Total Upah Operator }\end{array}$ & 10,2 unit & 17.500 & 100 & 17.850 .000 \\
\end{tabular}

(Dokumen Pekerjaan Pembangunan Bendungan Margatiga Lampung Timur, oleh PT. JMB 2020)

Tabel 8. Biaya Upah Untuk Pekerja

\begin{tabular}{lcccc}
\hline \multicolumn{1}{c}{ Jenis Pekerja } & $\begin{array}{c}\text { Jumlah } \\
\text { Pekerja }\end{array}$ & Jam Kerja & $\begin{array}{c}\text { Upah } \\
\text { Per Jam }\end{array}$ & Jumlah \\
\hline Pelaksana Lapangan & 1 orang & 100 Jam & 30.303 & 3.030 .300 \\
Mandor & 1 orang & 100 Jam & 15.152 & 1.515 .200 \\
Pencatat Ritase & 1 orang & 100 Jam & 8.182 & 818.200 \\
Total Upah Pekerja & & & 5.363 .700 \\
\hline
\end{tabular}

(Dokumen Pekerjaan Pembangunan Bendungan Margatiga Lampung Timur, oleh PT. JMB 2020) 


\section{Perhitungan Analisis Kombinasi Alat Berat}

Berikut ini adalah beberapa perhitungan alternatif yang akan di analisis bedasarkan perhitungan produksi alat berat dan biaya sewa alat berat denganpenjelasan secara teknis pengerjaan. Disini penulis hanya mencari alternative produktivitas alat berat Excavator dan Dumptruck. Disini peneliti tidak menghitung tentang produktivitas alat berat Bulldoser dan Vibratory Roller, sebab kedua alat berat ini tidak menjadi alat angkut atau pemindah tanah hasil galian untuk dibawa ke lokasi timbunan atau lokasi pembuangan. Bulldozer dalam pembangunan Bendungan Margatiga Lampung Timur berfungsi sebagai perata jalan yang akan di lalui Dumptcruk, mengupas jalan tanah yang basah setelah hujan, penghampar tanah hasil galian yang diangkut oleh Dumptruckmenuju lokasi pembuangan. Penempatan alat berat Bulldozer dalam laoksi pekerjaan berada dilokasi pembuangan hasil galian, lokasi timbunan dan jalan tanah yang akan dilalui Dumptruck. Alat berat Vibratory Roller berfungsi sebagai pemadat tanah hasil timbunan dan pemadat tanah jalan yang akan dilalui Dumptruck. Peran Bulldozer dan Vibratory Roller sangat penting karena sangat membatu proses Dumptruck melakakuan pemindahan tanah. Kombinasi alat berat yang baik dapat meningkatkan produktivitas dari masingmasing alat berat yang menjadikan waktu pengerjaan lebih cepat.

Tabel 9. Hasil Perhitungan Alternatif 1 Perhitungan Produktivitas Dan Biaya Sewa Alat Berat

\begin{tabular}{|c|c|c|c|c|}
\hline Jenis Alat & $\begin{array}{c}\text { Jumlah } \\
\text { Alat }\end{array}$ & $\begin{array}{c}\text { Kapasitas } \\
\text { Alat }\end{array}$ & Waktu & Biaya \\
\hline Excavator SANY SY365 & 2 unit & $2,1 \mathrm{~m}$ & 95 jam & 114.950 .000 \\
\hline Bulldozer & 2 unit & 4,4 & $95 \mathrm{jam}$ & 128.250 .000 \\
\hline Vibratory Roller & 1 unit & 10,5 ton & $95 \mathrm{jam}$ & 35.625 .000 \\
\hline Dumptruck & 10 unit & $24 \mathrm{~m}$ & 95 jam & 318.250 .000 \\
\hline Total Biaya Sewa Alat & & & & 597.075 .000 \\
\hline
\end{tabular}

Tabel 10. Hasil Perhitungan Alternatif 2 Perhitungan Produktivitas Dan Biaya Sewa Alat Berat

\begin{tabular}{|c|c|c|c|c|}
\hline Jenis Alat & $\begin{array}{c}\text { Jumlah } \\
\text { Alat }\end{array}$ & $\begin{array}{c}\text { kapasitas } \\
\text { alat }\end{array}$ & waktu & biaya \\
\hline Excavator SANY SY365 & 2 unit & $0,8 \mathrm{~m}$ & 204 jam & 222.360 .000 \\
\hline Bulldozer & 2 unit & 4,4 & 204 jam & 275.400 .000 \\
\hline Vibratory Roller & 1 unit & 10,5 ton & 204 jam & 76.500 .000 \\
\hline Dumptruck & 10 unit & $30 \mathrm{~m}$ & 204 jam & 683.400 .000 \\
\hline Total Biaya Sewa Alat & & & & 1.257 .660 .000 \\
\hline
\end{tabular}

Hasil Perhitungan Lapangan Dan Hasil Perhitungan Alternatif

Dalam pembahsan ini penulis akan memaparkan hasil seluruh pekerjaan alat berat pada Pembangunan Bendungan Margatiga Lampung Timur, adapun alat berat yang digunakan adalah Excavator, Bulldozer, Vibratory Roller dan Dumptruck. Dalam pekerjaan Galian dan Timbunan didapat pekerjaan hasil galian dan timbunan sebesar $14.118 \mathrm{~m} 3$. Yang mana $1.098 \mathrm{~m} 3$ digunakan sebagai timbunan lantai muka apron hulu dan $13.020 \mathrm{~m} 3$ tanah yang tidak terpakai dibawa ke lokasi pembuangan. Disini penulis memberikan perhitungan alternatif kombinasi alat berat untuk membandingkan kebutuhan biaya sewa alat berat dan kebutuhan jam operasional kerja, adapun hasil rekapitulasi perhitungan lapangan dan perhitungan alternatif dapat di lihat pada gambar 1 .

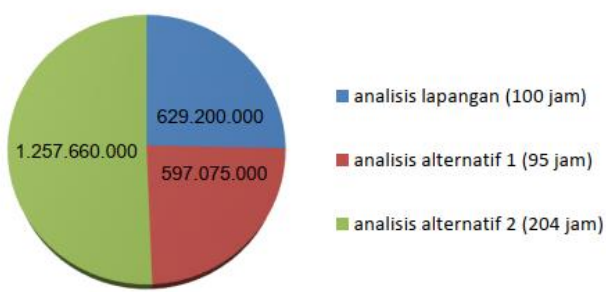

Gambar 1. Diagram Hasil Perhitungan Analisis Lapangan Dan Analisis Alternatif (Sumber : Penelitian Pembanguan Bendungan Margatiga Lampung Timur)

Dari perhitungan analisis lapangan dan dua perhitungan analisis alternatif didapatkan biaya paling ekonomis yaitu perhitungan alternatif 1 dengan total 
biaya sewa alat berat 605.200.000 dengan waktu 95 jam.

\section{Kebutuhan Cadangan Alat Berat}

Cadangan alat berat untuk dilokasi pekerjaan sangat dibutuhkan, karena dengan adanya cadangan alat berat bisa memaksimalkan hasil pekerjaan yang ada dilapangan. Dengan kondisi atau lokasi pekerjaan yang beratdan pengoprasian alat berat setiap harinya bisa menyebabkan terjadinya kerusakan pada mesin atau bagian-bagian dari alat berat.

Tabel 11. Kebutuhan Cadangan Alat Berat Pada Pembangunan Bendungan Margatiga Lampung Timur

\begin{tabular}{ccc}
\hline Jenis Alat Berat & $\begin{array}{c}\text { Jumlah Alat Berat } \\
\text { Yang Ada dilapanan }\end{array}$ & $\begin{array}{c}\text { Kebutuhan Cadangan } \\
\text { Alat Berat }\end{array}$ \\
\hline Excavator & 2 unit & 1 unit \\
Bulldozer & 2 unit & 1 unit \\
Vibratory Roller & 1 unit & 1 unit \\
Dumptruck & 10,2 unit & $2-3$ unit \\
\hline
\end{tabular}

\section{KESIMPULAN}

Setelah melakukan proses analisis maka terdapat beberapa kesimpulan yang dihasilkan adalah sebagai berikut:

1. Pengambilan waktu siklus langsung diambil oleh peneliti pada pembanguan Bendungan Margatiga Lampung Timur, jalan menuju lokasi pembuangan tanah hasil galian yang kurang baik setelah turun hujan menjadi hambatan bagi Dumptruck yang berdampak pada waktu siklus yang lebih lama serta menurunkan produktivitas alat berat. Dengan adanya Bulldozer dan Vibratory Roller membantu memaksilkan kinerja Excavator dan Dumptruck Dalam pemindahan tanah hasil galian. Total pekerjaan alat berat untuk galian dan timbunan adalah sebesar $14.118 \mathrm{M}^{3}$, yang terdiri dari pekerjaan galian sebanyak 13.020 $\mathrm{M}^{3}$ dan pekerjaan timbunan sebanyak $1.098 \mathrm{M}^{3}$.
2. Dari perhitungan analisis lapangan dan dua perhitungan analisis alternatif didapatkan biaya paling ekonomis yaitu perhitungan alternatif 1 dengan total biaya sewa alat berat 605.200.000 dengan waktu 95 jam.

\section{DAFTAR PUSTAKA}

Bambang, H., Dinihari, D. M., \& Rizky, f. 2020. Kuantitatif Alat Berat Untuk Item Pekerjaan Galian Dan Timbunan.(Studi Kasus Peningkatan Jalan Kecamatan Ciruas-LebakwangiPontang-Tirtayasa) Kabupaten Serang. Serang Banten.

Dewi, U.S. dan Jaya.H.F. 2019. Produktvitas Penggunaan Alat Berat Pada Proyek Pembangunan Jalan Tol Trans Sumatera. Studi Kasus: Paket III Kota Baru-Metro Sta 102+775 $103+225)$.

Universitas Muhammadiyah Metro.

Denny, D. P. 2017. Optimalisasi Penggunaan Alat Berat Pada Proyek Pembangunan Underpass Mayjen Sungkono Surabaya. Surabaya.

Gilang, A. 2014. Perbandingan Estimasi Pembiayaan Alat Berat Pada Proyek Pembangunan Gateway Pasteur Apartement. Universitas Pendidikan Indonesia

Ika, A., Puji, W., \& Arif. M. 2017. Analisa Produktivitas Alat Berat Pada Pembangunan Jalan Ruas Lingkar Pulau Marsela Provinsi Maluku Barat Daya.Jawa Barat..

Kementrian Pekerjaan Dan Perumahan Rakyat Direktorat Jendral Sumber Daya Air Balai Besar Wilayah Sungai Mesuji Sekampung. (2016). Rencana Kegiatan Pembangunan Bendungan Margatiga. Bandar Lampung. 
Kholil, A. 2012. Alat Berat. Remaja Rosda karya Offset. Bandung.

M, irfan. 2018. Analisis Pemilihan Alat Berat Pada Pekerjaan Galian Dan Timbunan Proyek Pembangunan Fakultas Hukum UII. (Heavy Equipment Choice Analysis On Cut And Fill Work Of UII Law Construction) Yogyakarta.

Mubarak, A. 2014. Perencanaan Pemakain Alat Berat Pada Pekerjaan Tanah Proyek Pembangunan Jalan Tol Surabaya-Mojokerto Sek IV.3 STA $\quad 37+297 \quad$ s/d 42+800.Surabaya.

Nursin, A. 1995. Alat Berat. Pusat Pengembangan Pendidikan Politeknik Bandung

PT JMB. 2020. Dokumen Pekerjaan Pembangunan Bendungan Margatiga Lampung Timur. Margatiga Lampung Timur.

Rasyid, R.M. 2008. Analisis Produktivitas Alat Berat Proyek Studi Kasus Proyek Pengembangan Bandar Udara Hasanudin Makasar. UMJ.

Rochmanhadi. 1984. Perhitungan Biaya Pelaksanaan Dengan Menggunakan Alat-Alat Berat. Departemen Pekerjaan Umum Badan Penerbitan Pekerjaan Umum. Jawa Tengah..

Rostiyanti, F.S. 2008. Alat Berat Untuk Proyek Konstruksi. Rineka Cipta. Jakarta.

Sugiono. 2015. Metode Penelitian Kombinasi (Mix Methods) Bandung. Alfabeta

Terensuki, A. 2013. Pemindahan Tanah Mekanis. Jakarta. Gunadarma..

Wiopo, D. 2009. Metode Konsrtuksi dan Alat-Alat Berat. Universitas Indonesia. Jakarta 